\title{
INTRODUCTION: \\ PHYSICALITY, SPIRITUALITY, AND CHINESE PHILOSOPHY
}

Originally conceived as a special issue applying Chinese philosophy to topics in philosophy of sport, it soon became clear that a broader heading was necessary to do justice to the distinctive character of Chinese philosophy. The choice of "physicality" obviously does not preclude sport and athleticism, but it also does not confine the focus to competition or physical fitness. The addition of "spirituality" acknowledges the link between this mode of being and that of the physical, further broadening the horizon of perspectives taken by the contributors in the articles herein. With this special issue, we highlight several ways in which Chinese philosophy can productively contribute to contemporary philosophical issues related to physicality and spirituality.

Peimin Ni explores the prospects of basing a gongfu ethics on the basis of classical Chinese ethical theories in "Can Bad Guys Have Good Gongfu? A Preliminary Exploration of Gongfu Ethics." As Ni indicates, the term gongfu distinctively links mind to the body, action to the agent, and aesthetics to the entire realm of life. While martial arts constitute a familiar and paradigmatic example of gongfu, its core meaning is the art of life in general, including efforts, methods, and cultivated and embodied methods of living well. Ni makes the case that instead of taking the human subject for granted as rational choice makers, gongfu takes ethics as mainly a matter of cultivating the subject so that people can become artists of living. This cultivation has to include the training of one's body and emotions, and not merely the ability to think well. Ni concludes with thoughts on the potential of gongfu perspectives informing global dialogues on ethics.

The next two papers address ethical issues that often take center stage during Olympic contests and other high profile athletic events. In recent years, a rash of athletic achievements has been besmirched by revelations of athletes having enhanced their performances by using banned substances. Christopher Panza brings Chinese

MATHEW A. FOUST, Associate Professor, Department of Philosophy, Central Connecticut State University. Specialties: classical Chinese philosophy, classical American philosophy, comparative philosophy. E-mail: foust@ccsu.edu

Journal of Chinese Philosophy 43:1-2 (March-June 2016) 6-8

(C) 2018 Journal of Chinese Philosophy 
philosophy to bear on this problem in "Flourishing, Sports, and Doping: A Confucian Virtue-Ethical Meditation." Enlisting zhong, shu, and ren as fundamental values, Panza develops a Confucian-inspired account of flourishing in the context of sport that requires harmonization with one's role as an athlete, and contribution to the flourishing of fellow sports practitioners.

In "Sages, Heroes, and the Battle for Cycling's Soul," Heather L. Reid compares the relationship between Chinese sages and virtuous practitioners to the ancient Greek relationship between heroes and athletes. Reid argues that de is the soul of cycling and that ancient Chinese philosophy's insights into conditions that promote de can function as antidotes to modern cycling's overemphasis on technology, commercialism, and the individual. Emphasizing the spontaneous virtuosity of wuwei, Reid describes the distinctive sense of community felt by spectators and athletes in a cycling event a form of collective awareness of the presence of Dao.

The reactions of spectators to athletes serve as one motivation for David Elstein's paper, "A Confucian Perspective on LeBron and Loyalty." Elstein reflects upon the ethics of one the most renowned and influential athletes of our time, LeBron James. Using LeBron James's departure from the NBA's Cleveland Cavaliers in 2010 as a case study, Elstein examines the question of athletes' loyalty to their team and to their region, through the lens of Confucian ethics. While acknowledging a Confucian impulse toward loyalty and community that might suggest condemnation of James's actions, Elstein maintains that James's decision and subsequent actions would probably be permissible from a Confucian perspective.

Expanding the purview of this collection to include attention to nonhuman animals, Heather E. Keith discusses physicality and spirituality in "The Dao of Dressage: Mysticism and Aesthetic Experience in Equestrian Sports." Drawing significantly from the Daodejing, Keith treats themes and imagery from Daoism such as non-contention, flow, humility, and mysticism, holding that these concepts can help riders to unpack and enhance the experience of working with a nonhuman teammate. Comparing these notions from Daoism with John Dewey's aesthetics and the psychology of "flow," Keith articulates a nuanced relationship between athleticism and artistic value in formal equestrian sports.

Global dialogues on ethics motivate the paper by Li-Hong (Leo) Hsu and Jesús Ilundáin-Agurruza, "An Inquiry on the Compatibility between East Asian Confucianisms and Modern Olympism: A Humanistic and Global Perspective." Because sports are often conceptualized as social practices, and Olympic Games are venues in which these practices play out on an international stage, Hsu and 
Ilundáin-Agurruza contend that the time is ripe for Modern Olympism to engage in dialogue with East Asian values, and in particular, varieties of Confucianism. This discussion is timely, with China having hosted the 2008 Olympic Summer Games and scheduled to host the Olympic Winter Games in 2022. Hsu and Ilundáin-Agurruza contend that despite initial appearances, a deep current connects Confucianism and Modern Olympism in mutually beneficial ways.

This project would not have come to fruition without the encouragement and dedication of Professor Chung-ying Cheng and Dr. Linyu $\mathrm{Gu}$, and the insightful work of our contributors and reviewers. To each I express my gratitude. 